IJIET, e-ISSN 2548-8430, p-ISSN 2548-8422, Vol. 1, No. 2, July 2017

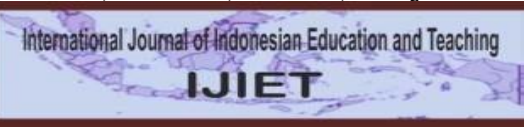

International Journal of Indonesian Education and Teaching

http://e-journal.usd.ac.id/index.php/IJIET

Sanata Dharma University, Yogyakarta, Indonesia

\title{
THE SOCIAL PERSONALITY AUTONOMY COMPETENCE AMONG JUNIOR HIGH-SCHOOL STUDENTS
}

\author{
Juster Donal Sinaga \\ Guidance and Counseling Study Program \\ Faculty of Teacher Training and Education, Sanata Dharma University \\ donalsinaga@usd.ac.id \\ https://doi.org/10.24071/ijiet.2017.010202 \\ received 25 November 2016; revised 20 January 2017; accepted 1 July 2017
}

\begin{abstract}
The autonomy competence in the social personality of the adolescents became one of the development aspects which must be urgently acquired by adolescents. Failure to be autonomous in the social personality during the adolescence period would have bad impact in the subsequent ages. The aims of the research were (1) to describe the level of autonomy competence of social personality in one of private Junior High schools, (2) to identify the items of the Inventory of Adolescent Social Personality Autonomy Competence (IASPAC) in the low and very low categories as the base to propose the topics of social personality guidance in one of the private junior high schools in Yogyakarta. The research subjects were the 141 students in grades VII, VIII, and IX. The research instrument was Inventory of Adolescent Social Personality Autonomy Competence (IASPAC) numbering 39 items which were composed by the researcher on the ground of the autonomy competence standards in the American School Counselor Association (ASCA) model, at the reliability value of 0.935 . The data analysis was descriptive analysis with the categorization of the average numbers. The research result showed that as a whole the autonomy competence in the social personality of the students in one of the private junior high-schools in Yogyakarta was categorized as 'autonomous', with the following details, 18 students $(12.7 \%)$ were categorized as 'very high', 104 students $(73.7 \%)$ were categorized as 'high', 19 students $(13.48 \%)$ were categorized as 'medium', and none of the students were categorized as 'low' and 'very low'. There were many differences in the average of the social personality autonomy competence among the grade VII, VIII, and IX students. The grade VII students' level of social personality autonomy competence was higher than that of the grade VIII and IX students. The other finding was that there were 10 items of the IASPAC with the lowest scores. These items would be used as the basis to propose topics for classical guidance of the social personality.
\end{abstract}

Keywords: autonomy competence, social personality, classical guidance 


\section{Introduction}

The adolescence period, one of the phases in human development, is a period with peculiar characteristics. In the developmental process, there are a number of influential factors, namely congenital and environmental factors. The adolescent is individual whose age is outspread between the end of childhood and the beginning of adulthood.

In the developmental period, adolescents carry the developmental tasks. The developmental tasks cover attitudes, behavior, and skills which should be acquired and accomplished in every phase of the developmental ages. According to Havighurts (Danim, Sudarman and Khairil, 2011), developmental tasks comefrom three sources: (1) physical maturity; (2) socio-cultural and cultural strengths;

(3) cultural values and aspirations.

Psychologically, adolescence is a period full of potentials, vitality, and dynamics, albeit unstable. According to Erik Erikson (in Kail, Robert V and Cavanaugh, John C, 2007: 340), "adolescents face a crisis between identity and role confusion". It means that adolescence is the period of identity crisis and role confusion. In this phase, adolescents set up the balance by trying many chances and fulfill many kinds of need independently, but they did not explore many of their own alternative identities (Kail. Robert V and Cavanaugh, John C, 2007)

The success of adolescents in going through their adolescence is influenced by the changes of family life patterns, economic-cultural-social conditions, and the global situation. An adolescent who is able to accomplish his or her developmental tasks well will have healthy personality and develop optimally. Healthy personality and optimal development can be seen from adolescents' behavior and achievement.

One of the dimensions of adolescent development is social personality development. Yusuf (2006) said, the social development was the maturity achievement in the social relation and could be interpreted as the learning process to adapt themselves to the group norms, morals, and traditions; to melt themselves into one unity, to communicate to each other, and to work together.

Furthermore, Yusuf (2006) said that in the adolescent ages, there were developmental tasks and social personality competence which should be acquired by the adolescents. At this age, adolescents should have gained the competencies: 1) knowledge, attitude, and interpersonal skill to help them understand and respect themselves and others, and 2) the ability to make decision to establish goals and to take actions needed to achieve the goals. However, some adolescents' autonomy competence in social personality is still low. On the contrary, there are adolescents who have problems in social personality. The problems are potentialto harm their lives.

The phenomena of adolescents having personal and social problems, such as not accepting themselves, not being able to socialize with the environment, getting involved in brawls, abusing drugs, bullying and being bullied, getting involved in robbery, getting involved in prostitution, and other personal problems, are alarming. Almost every day, juvenile delinquency is reported in the media, both in mass media and electronic media. 
To cite one example, the result of a research implemented to 180 adolescents in Kudus District indicated that $94 \%$ of the subjects said they have treated others unkindly. The bad treatments include mocking and calling names. The targets, the victims of their bad treatments, were $50 \%$ the classmates, $16 \%$ their juniors, $14 \%$ other school students, $7 \%$ their seniors, $5 \%$ the teachers and 8

$\%$ (Mahardayani, 2010).

The broader research was carried out by SEJIWA, Plan Indonesia and University of Indonesia involving around 1233 students of elementary schools, junior high-schools, and senior high-schools in Jakarta, Yogyakarta, andSurabaya. The result of the research showed that the violence among students in junior highschools happened in Yogyakarta (77.5\%), Jakarta (61.1\%), and Surabaya (59.8\%) consecutively. Violence in senior high-schools mostly happened in Jakarta $(72.7 \%)$, followed by Surabaya $(67.2 \%)$, and the last in Yogyakarta $(63.8 \%)$ (www.Sejiwa.org).

Starting from the background of this study, a clear and valid description of the level of junior high-school students' social personality autonomy competence must be made. Does the level of junior high-school students' social personality autonomy competence reflect the present condition of adolescents? This research aimed at describing the high/low levels of students' social personality autonomy competence in one of the private junior high-schools in Yogyakarta, in the academic year of 2014/2015. Besides, this research identified items of Inventory of Adolescent Social Personality Autonomy Competence (IASPAC) of which intensity is low in shaping students' social personality autonomy competence in one of the private junior high-schools as the basis to propose topics of social personality guidance.

The Autonomy Competence Standards (ACS) are the students' achievement covering the effort of development and realizing the students' self- potentials as a whole in personal, social, learning, and career aspects. In the Regulation of the Minister of Education Number 23 of 2006 on the Graduate Competence Standards for Elementary and Secondary Education, it is elaborated that the graduate competence should be achieved by the students through learning various lessons.

In the context of guidance and counseling, the graduate competence isknown as the Autonomy Competence Standards (ACS), which covers ten aspects of individual (elementary and secondary students) development. The Directorate General of Quality Improvement for Teachers and Education Personnel's, Minister of National Education (2007) formulated ten aspects of the development as follows:

(1) Foundation of Religious Life; (2) Foundation of Ethical Behavior;

(3) Emotional Maturity; (4) Intellectual Maturity; (5) Sense of Social Responsibility; (6) Gender Awareness; (7) Self-development; (8 ) Entrepreneurship Behavior (the autonomy of economical behavior); (9) Insightand Preparedness for the Career; (10) Maturity of Relationship to friends of the same age.

Each aspect has three goal dimensions, namely: (1) recognition/awareness (getting the knowledge and understanding about the developmental aspects and tasks/competence standards that should be mastered); (2) accommodation 
(obtaining meaning and internalization of developmental aspects and tasks/competence standards to be mastered), and: (3) action (the actual behavior in the daily life of developmental aspects and tasks/competence standards to be mastered).

The developmental aspects and the dimensions had seemingly been composed in such a way to follow and be aligned with the principles, norms, and the developmental aspects and tasks that should be achieved by the individuals. Table 1 is the formulation of Autonomy Competence Standards for the Students in Junior High-schools (Kartadinata, et. al, 2002).

Table 1. The Developmental Aspects and Dimensions

In Junior High-school

\begin{tabular}{|c|c|}
\hline & Goal Level/Internalization \\
\hline INo & Accommodation \\
\hline 1 & $\begin{array}{l}\text { of Recognizing the Being interested in } \begin{array}{l}\text { Implementing many } \\
\text { meaning and the goal learning the meaning and kinds of worshiping on } \\
\text { of worship } \\
\text { the goal of worship }\end{array} \\
\end{array}$ \\
\hline 2 & $\begin{array}{lll} & \text { Knowing the reason Understanding the variety } & \\
\text { Foundation } & \text { of to necessarily obey of the rules/norms to Acting on their personal } \\
\text { Ethical Behavior } & \begin{array}{l}\text { consideration of thevalid } \\
\text { the rules/norms to behave in the context of } \\
\text { behave }\end{array} \\
\end{array}$ \\
\hline 3 & $\begin{array}{c}\text { Recognizing the Understanding the variety } \begin{array}{l}\text { Expressing the feeling } \\
\begin{array}{c}\text { Emotional Maturity ways to express the of expressions of } \\
\text { feeling normally }\end{array}\end{array} \begin{array}{l}\text { based on the contextual } \\
\text { themselves and others }\end{array} \\
\end{array}$ \\
\hline 4 & 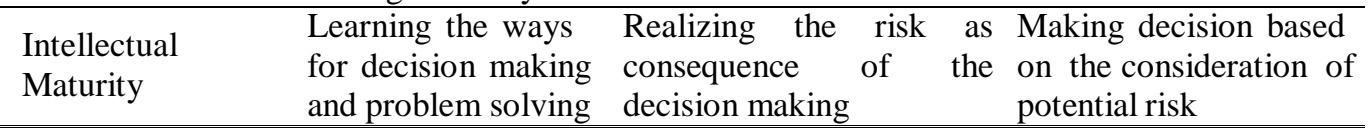 \\
\hline 5 & $\begin{array}{lll} & \text { Learning the ways to Appreciating the values of } & \text { Interacting with other } \\
\text { Sense of Social } & \text { obtain the rights and friendship and harmony in people based on the } \\
\text { to carry on duties in the daily life } & \text { values of friendship and } \\
\text { Responsibility } & \text { the daily life } & \text { life harmony } \\
\text { environment } & \end{array}$ \\
\hline 6 & 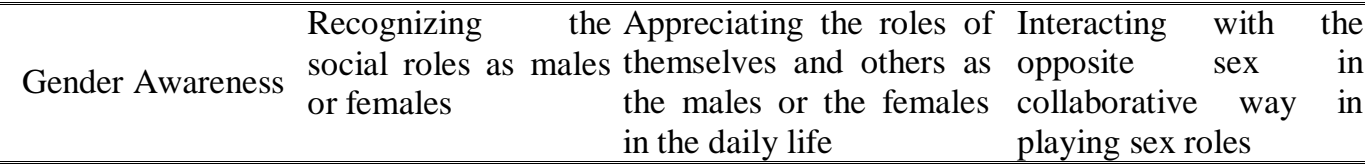 \\
\hline 7 & $\begin{array}{ll}\text { Recognizing their Accepting personal } & \begin{array}{l}\text { Believing their personal } \\
\text { uniqueness as the asset } \\
\text { personal ability and } \\
\text { will }\end{array} \\
& \begin{array}{l}\text { that should be developed } \\
\text { harmoniously in the } \\
\text { daily life }\end{array} \\
\end{array}$ \\
\hline 8 & 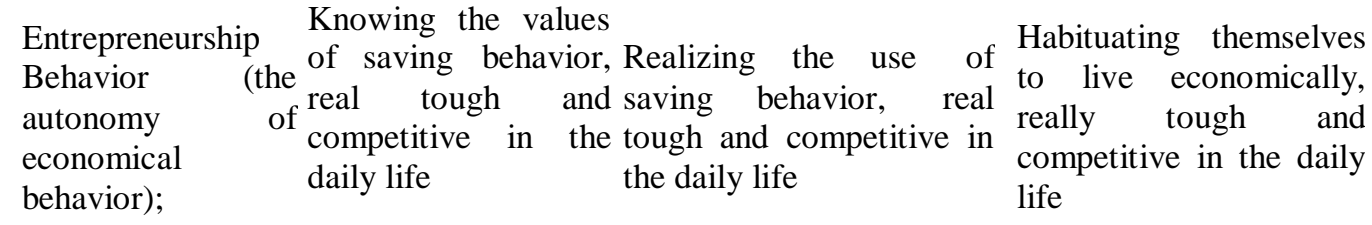 \\
\hline 9 & 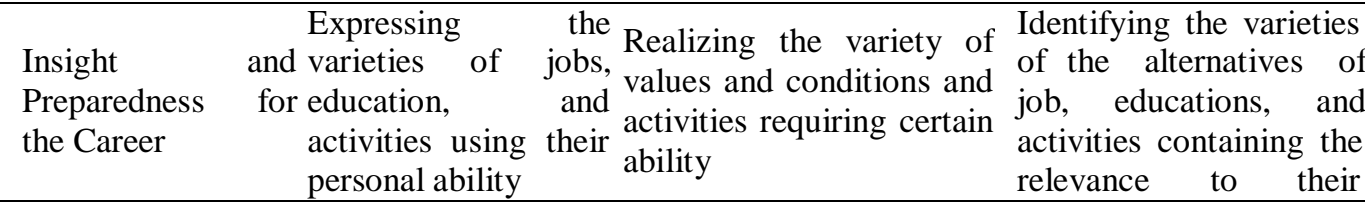 \\
\hline
\end{tabular}




\begin{tabular}{|c|c|c|c|c|}
\hline \multirow[b]{2}{*}{ No } & \multirow{2}{*}{$\begin{array}{l}\text { Developmental } \\
\text { Aspects }\end{array}$} & \multicolumn{3}{|c|}{ Goal Level/Internalization } \\
\hline & & Recognition & Accommodation & Action \\
\hline & & & & personal ability. \\
\hline 10 & $\begin{array}{l}\text { Maturity } \\
\text { Relationship } \\
\text { friends of the } \\
\text { age. }\end{array}$ & $\begin{array}{l}\text { Learning the norms } \\
\text { of of the } \\
\text { to intercommunication } \\
\text { ame with friends of the } \\
\text { same age from } \\
\text { various back grounds }\end{array}$ & $\begin{array}{l}\text { Realizing the various } \\
\text { backgrounds of the } \\
\text { friends of the same age } \\
\text { that underlie the } \\
\text { intercommunication }\end{array}$ & $\begin{array}{l}\text { Working together with } \\
\text { the friend of the same } \\
\text { age from various back } \\
\text { grounds }\end{array}$ \\
\hline
\end{tabular}

In the document of ASCA National Standards for Students (2004), three (3) fields of guidance, namely academic, career, and social personality are elaborated. Each field consists of some competence standards. Each competence standard consists of a number of competencies. Every competence consists of a number of indicators.

The academic field consists of 3 (three) competencies, namely:

1) students will acquire the attitudes, knowledge and skills that contribute to effective learning in school and across the life span, 2) students will complete school with the academic preparation essential to choose from a wide range of substantial post-secondary option, including college, 3) students will understand the relationship of academics to the world of work and to life at home and in the community.

In the career field, there are 3 (three) competence standards, namely;

1) Students will acquire the skills to investigate the world of work in relation toknowledge of self and to make informed career decisions, 2) students will employ strategiesto achieve future career goals with success and satisfaction, 3) students will understand the relationship between personal qualities, education, training and the world of work.

Meanwhile in the social personality field, there are also 3 (three) basic competencies. Firstly, the students acquire the knowledge, attitudes, and interpersonal skills to help them understand and respect themselves and others. This competence standard consists of 2 (two) competencies, namely, acquiring self knowledge and interpersonal skills. Secondly, the students are able to make decision to set goals, and take necessary action to achieve the goals. This competence standard consists of one competence, namely being able to apply self-knowledge. Thirdly, the students are able to understand the safety and survival skills. This competence standard consists of one competence, namely, acquiring personal safety skill.

From the three competencies in the social personality which was developed by ASCA Model, there are three competence levels, namely, knowledge, attitude, and skill. Of the three competence levels, if they are elaborated in the field of human ability, the knowledge level is included in the field of cognition ability, thelevel of attitude is included in the field of affective ability, and the level of skill is included in the field of psychomotor ability or the will (conation).

The social personality competence encompasses various activities that help students develop their interpersonal skills individually and in groups. This field was based on students' goal to achieve the academic, career, and life success, and also the development of strong positive self-concept (Rusmana, 2009).

The social personality guidance is an effort to help individuals cope with their mental situation and overcome the inner conflict, manage themselves in the fields of religion, physical treatment, the leisure time fulfillment, channeling the 
sexual desire, and effort to help individual establish the social relations in many environment or association (Winkel, 1997). In other words, social personality guidance is a field of service that helps the students in understanding and evaluating and developing the effective and healthy social relation ability with thefriends of the same age, family members, and the people in the wider social environment. The social personality guidance is a guidance to assist individuals tosolve their personal problems. The social personality guidance is also understood as the guidance to help students in developing self-potentials and social relation ability and to solve social personality problems (Yusuf, 2006). The problems that are categorized into the social personality problem are the problems of the relationamong friends, understanding personal characters and ability, self adaptation tothe environment and society where they live in, and also the conflict resolution.

Social personality guidance is a process to facilitate students to be able to develop understanding and the skill to get engage in social interaction, and to solve their social problems. Social personality guidance covers the development of: (a) the understanding of the diversity of tribes and cultures; (b) social attitudes (empathy, altruistic, tolerant, and cooperative); and (c) the ability to socially communicate in a positive manner (Yusuf, 2009).

Furthermore, (Yusuf, 2009) explained that social personality guidance was aimed at establishing personality and developing individual ability in handling their own problem. This guidance is the service directed to obtain balanced personal achievement regarding the uniqueness of characteristic and also the various problems faced by the individuals. Social personality guidance is given bycreating conducive environment, friendly educational interaction, developing the system for self-understanding and positive attitudes, and appropriate social skills.

Prayitno (1997:66) said, "In the context of social personality guidance, the guidance is aimed at assisting the students to know and communicate with their social environment on the ground of the noble character, social and national responsibility. Moreover, Prayitno mentioned the principles of social guidance, they are: (a) establishment of effective communication skill, both written and oral; (b) establishment of accepting and expressing opinion and arguing dynamically and productively; (c) establishment of ability to behave and communicate socially, at home, in school, and in wider society by upholding ethics, politeness, and religious values, customs, law, science and the prevailing habits; (d) establishment of dynamic, harmonious, and productive relation with friends of thesame age, at the same school, at other schools, outside schools, or in the society ingeneral; (e) establishment of the understanding and the responsibility; and (f) the orientation of family life.

Social personality guidance aims at helping students to be able to develop their competence in the following manners: (a) respecting and appreciating other people; (b) be responsible and committed to the duties, social roles; (c) to be able to relate socially (human relationship); (d) to have good communication skill, both verbal and non-verbal; (e) to have the ability of self-adjustment.

In a specific way, the objective of guidance in relation to the SP is that the students: (a) have the strong commitment to practice the faith values and the devotion to the God almighty, in the personal life, family, the association with 
friends of the same age, at school/madrasah, work place, or the society in general; (b) have the attitudes of tolerance to other religious people, by respecting and maintaining the rights and duties one to each other; (c) have the understanding of life rhythm that is fluctuating between joy (gifts) and sorrow (misfortune), and be able to respond in positive way according to the religious teaching they adhere; (d) have the self-knowledge and self-acceptance objectively and constructively, both in relation to the strengths and weaknesses; both physically and psychologically; (e) have positive attitudes or respect to themselves or to other people; (f) have the ability to make a choice elegantly; (g) respect other people, honor or appreciate other people, not harassing their dignity; (h) have a sense of responsibility which is realized in the form of commitment to the tasks or duties; (i) have the ability to interact socially (human relationship), which is realized in the forms of friendship relation, family ties, hospitality to one another; (j) have the ability to resolve conflict (problems), both internally and externally; and (k) have the ability to make decision effectively.

From table 1, the process of absolving the students in achieving personal and social competence as one of the goals of guidance and counseling is clearly stated. In order for the students to have autonomy in the field of social personality, the service of guidance and counseling is present to give assistance in many kinds of services (Yusuf, 2009). In those kinds of services, the goals of services are designed in sequence and phases which are called internalization phase, starting from recognition, accommodation, and finally action. The achievement of the three phases of internalization shows the students' autonomy level.

Nurihsan and Sudianto (2005) mention that the goals of the social personality guidance at the end help individuals to achieve: (a) personal happinessin life as God's creation; (b) productive and effective life in the society: (c) living together with other individuals; and (d) harmony between their idols and the acquired ability.

If seen from the point of view of comprehensive guidance and counseling, the social personality guidance is given through the basic service component or guidance curriculum. The basic service component is the process of giving assistance to all counselees through the activities of preparing the structured experience classically or in groups which is presented systematically in terms of developing the long-term behaviors in accordance to the developmental phases and tasks (which are elaborated as the autonomy competence standards) that are needed in developing the ability to choose and make decision in living their lives. The basic services are expected to be able to facilitate the improvement of certain knowledge, attitude, and skill inside the students that is appropriate and suitable to the developmental phase.

There are at least three functions of guidance, namely: (1) the function of development, that is, the guidance function in developing all individuals' potentials and strengths; (2) the function of channeling, that is, guidance function to help the individuals choose and determine the mastery of career or job in accordance to the interest, talent, expertise, and other personal characteristics; (3) the function of adaptation, that is, guidance function to help the individuals find self-adaptation and development optimally (Nurihsan, 2006). 
The adolescence period is a transitional period. The term adolescence is not simply that the individual grows toward adulthood that is prepared to make reproduction. It means that it does not see maturity from the physical factor only but it covers mental, emotional, and social maturity (Hurlock, 2004). The age of adolescents is around 13 to 16 years or it is commonly called desolate teenage. In this age, adolescents experience physical, psychological, and social changes. Harold Alberty (Makmun, 2003: 130) stated that, "the adolescence period can be defined in general as a period in the development which is experienced by individual ranging from the end of childhood period until the beginning of adulthood."

Piaget (Hurlock, 2004) mentions that psychologically, the adolescence period is the individual age to integrate with the adult society, the age when the child does not feel being under the level of older people but they are at the same level, at least in the matter of rights. When an adolescent integrates to the society (adult people) there are changes in the affective aspect and the striking intellectualchanges. The unique intellectual transformation from the adolescent way of thinking enables him or her to reach the integration to the social relationship to theadults of which, the reality becomes the common unique characteristics of the developmental period.

In the western thoughts, adolescence is seen as a transitional process to autonomy. In this period, certain characteristics appear like inappropriate behaviors, changes of mental situation, challenges of the customs and values regularly. A number of adolescent characteristics show the phase of adolescent developments.

Erikson (Hurlock, 2004), in his study, see the adolescent life as the identity crisis period. It means that the phase that the youngsters should create coherent identity and overcome the feeling of identity diffusion. The adolescents should make a big decision today in almost all fields of life, and each involves the crisis and needs to defeat the loss of identity. There are four things that influence this attitude. First, fear of intimacy, commitment and full involvement in close personal relation causes the loss of self and personal identity. Many adolescents need more time to be able to establish relation to others before they fully trust others in that relation. Second, the need to fight. Adolescents get into troubles to plan the future. There is ambivalence of the promising future possibilities: on onehand, they believe that time will bring changes, on the other hand, there are worries in those changes. The third is the industrial diffusion where the adolescentfeel difficult to utilize the resources in a realistic manner, either in the practical job or study. This is the powerless and redundant condition, the inability to concentrate or being preoccupied with a single activity and ignoring all other things. The fourth is that there is an attractiveness to create a negative identity, which contradict with what the adult or older people prefers. The will to oppose the process finds the true identity. It is stated as the denial to dislike the rolewhich is said to be respectful and appropriate for the family or community.

According to Havighurts (Hurlock, 2004), the developmental tasks appear at the time or around one certain period of individual life, of which if it is successful, it can give happiness and bring the direction toward the success in doing the next 
tasks. However, if it fails to execute the task, it will cause the unhappiness and troubles in facing the next tasks. Generally, the developmental tasks in every human developmental phase arise as a result of the physical maturity, the presence of cultural stresses from the society, and the individual values and aspiration which come up at the same time.

Further, Hurlock (2004:9) explains that the developmental task have the goals: 1) giving the indicators to the individual to find what the society expect from them at the certain ages, 2) giving motivation to each individual to do what the social group expect from them at certain age in their life span, 3) indicating each individual what they will face and what actions expected from them when they reach the next development level.

According to Huvighurst (Hurlock, 2004), there are 8 (eight) developmental task in the period of adolescence, namely 1) achieving the new and more matured relation with friends of the same age, both male and female, 2) achieving the male and female social roles, 3 ) accepting the physical condition and using their bodies effectively, 4) expecting and achieving the responsible social behavior, 5) achieving the emotional autonomy from the parents and other adults, 6) preparing economic career, 7) preparing marriage and family, and 8) acquiring a set of values and ethical system as the guide to act developing the ideology

\section{Method}

The approach used in this research was quantitative approach in the form of survey. The quantitative approach was used to describe the social personality autonomy competence level faced by the students in one of the private junior highschools in Yogyakarta in the academic year 2014/2015. The sampling technique was purposive sampling, namely, determining a certain sample on the ground of certain consideration (Sugiyono, 2010). The consideration to determine the sample was the representativeness of each class. The detail of the research subjects is shown in the table below.

Table 2. The Number of Research Subject

\begin{tabular}{lll}
\hline No & Grade & Total \\
\hline 1 & Grade VII & 34 students \\
\hline 2 & Grade VIII & 67 students \\
\hline 3 & Grade IX & 40 students \\
\hline & Total & 141 students \\
\hline
\end{tabular}

The research instrument was the Inventory of Adolescent Social Personality Autonomy Competence (IASPAC) in the form of a scale. IASPAC was developed by the researcher based on the social personality autonomy competence standards which was design by the American School Counselor Association (ASCA). IASPAC referred to the principles of Likert Scale. The stimulus of the instruments items was the junior high-school perception that described the achievement of social personality autonomy competence. The responses of the stimulus were to choose the answers which were provided in four alternative answers, namely Very 
Appropriate (VA), Appropriate (A), Indecisive (I), and Inappropriate (IA). The number of the IASPAC items before testing was 56.

Before testing the instrument, the readability testing was implemented to provide the feedback for the researcher concerning the description of easiness or difficulties which might be found by the population and the sample in understanding the given research instrument. The readability testing was done to 2 (two) students of grade VIII. Based on the readability testing, the instruments could be understood by the subjects of the readability testing.

After the readability testing, the instruments were tested to obtain the validity coefficient or internal consistency using the correlation testing of Pearson Product Moment (Azwar, 2005:59). The determination of item validity was based on the total-item correlation with the limit of $r_{i x} \geq 0.30$. All items that achieved minimum correlation coefficient 0.30 , the discriminating power was assumed to be satisfying, while the items with the correlation coefficient less than 0.30 , the discriminating power was assumed to be low (Azwar 2005;65). IASPAC was tested to the samples that had the same characteristic with the research respondents. The data calculation for validity testing used the computer programof SSPS version 16.0 (Statistical Program for Social Windows). The result of validity testing indicated empirically that 39 items had the correlation coefficient equal to or bigger than 0.30 . It means that the items were declared valid to be usedas the research item. 17 items were declared invalid and inappropriate to be usedas research instrument items.

The value of instrument $\mathrm{RC}$ was calculated using the product moment. RC could be considered as the indicator for measurement stability of the test from time to time (stability over time) (Azwar, 2013). The value of instrument RC was 0.935 . It was categorized as very high. It means that this instrument was very reliable to be used as the research instrument.

The data analysis technique used to obtain the description of the level of social personality autonomy competence faced by the students in one of private junior high-schools in Yogyakarta in the academic year of 2014/2015 was the categorization using the normal distribution by calculating the mean and the deviation based on the theoretical data. The categories were Very High, High, Low, and Very Low. To see the discrimination of the level of social personality autonomy competence between classes was also done descriptively using the value of the mean of each class.

\section{Findings and Discussion}

Based on the analyzed research data, it could be found that the level of social personality autonomy competence of the students in one of private junior high-schools in Yogyakarta in academic year 2014/2015, as follows 
Table 3. Level of social personality autonomy competence in one of private junior high-schools in Yogyakarta

\begin{tabular}{|c|c|c|c|c|c|c|c|c|c|}
\hline \multirow{2}{*}{$\begin{array}{l}\text { Range of } \\
\text { score }\end{array}$} & \multirow{2}{*}{ Category } & \multicolumn{2}{|c|}{ Grade IX } & \multicolumn{2}{|c|}{$\begin{array}{l}\text { Grade } \\
\text { VIII }\end{array}$} & \multicolumn{2}{|c|}{ Grade VII } & \multicolumn{2}{|c|}{ Total } \\
\hline & & f & $\%$ & $\mathbf{f}$ & $\%$ & f & $\%$ & f & $\%$ \\
\hline 164-195 & Very High & 6 & 15.00 & 4 & 5.97 & 8 & 23.53 & 18 & 12.77 \\
\hline $133-163$ & High & 29 & 72.50 & 54 & 80.60 & 21 & 61.76 & 104 & 73.76 \\
\hline $111-132$ & Medium & 5 & 12.50 & 9 & 13.43 & 5 & 14.71 & 19 & 13.48 \\
\hline $70-110$ & Low & 0 & 0.00 & 0 & 0 & 0 & 0 & 0 & 0 \\
\hline \multirow[t]{2}{*}{$39-69$} & Very Low & 0 & 0.00 & 0 & 0 & 0 & 0 & 0 & 0 \\
\hline & & 40 & & 67 & & 34 & & 141 & \\
\hline
\end{tabular}

From the table above, it can be identified:

1. The level of students' social personality autonomy competence in one of the private junior high-schools in Yogyakarta, in the category "very high", the number was 18 students $(12.77 \%)$. If seen in each class, the number of Grade VII students in the category "very high" was 8 students $(23.53 \%)$, higher than in Grade VII as many as 4 students (5.97\%), and inGrade IX as many as 6 students $(15 \%)$.

2. There were 104 students $(73.76 \%)$ of 141 students in one of the private junior high-schools in Yogyakarta in the category "high". If seen in each class, the number of the students in the category "high" was higher in Grade VIII reaching 54 students (80.60\%) compared with the Grade IX with 29 students (72.505) and in Grade VII as many as 21 students $(61.76 \%)$,

3. There were 19 students (13.48\%) of 141 students in one of the private junior high-schools in Yogyakarta in the category "medium". In each class, the highest percentage of the students in this category was the students in Grade VII, namely 5 students $(14.71 \%)$ followed by the Grade VIII as many as 9 students (13.43\%), and next in Grade IX as many as 5 students $(12.50 \%)$.

In general, the level of students' social personality autonomy competence in one of the private junior high-schools in Yogyakarta was in the category "high" and none of the students with the autonomy level in the category "low" and "very low". It means that the students in one of the private junior high-schools in Yogyakarta possessed the knowledge and awareness of development and realizingthe students' self-potential as a whole in the aspect of social personality. Visually, the profile of the level of students' social personality autonomy competence inone of the private junior high-schools in Yogyakarta, the academic year of 2014/2015 was shown in the following picture. 
IJIET Vol. 1, No. 2, July 2017

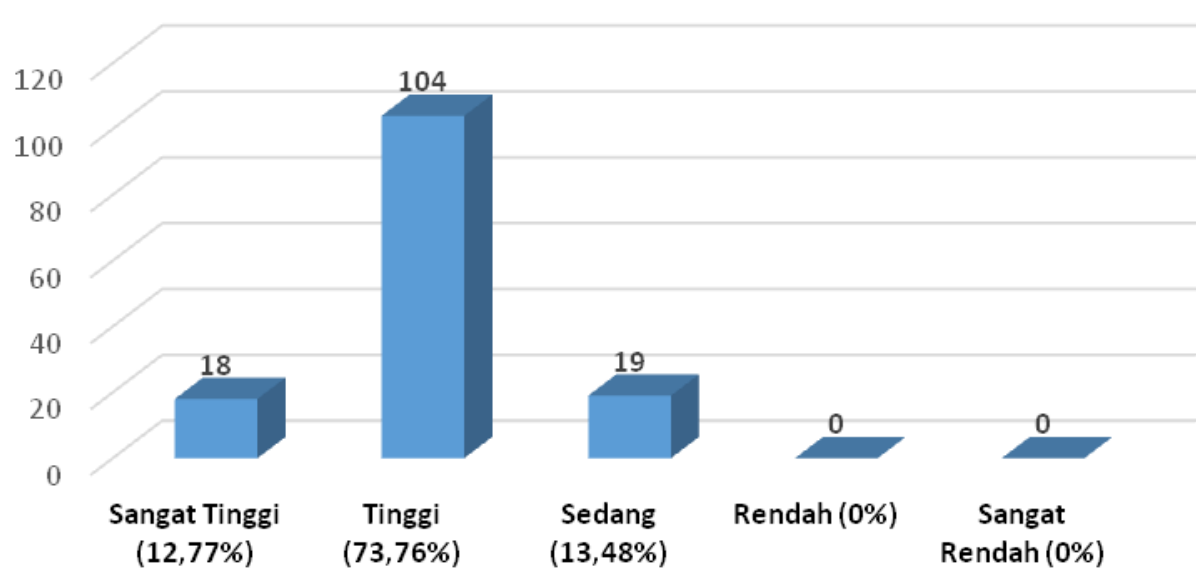

Picture 1: The Histogram of the Level of students' social personality autonomy competence in one of the private junior high-schools in Yogyakarta Academic year 2014/2015

Based on the item analysis of IASPAC which was analyzed on the ground of the mean value $423(n=141)$, there were not any IASPAC items below the mean value. It means that all IASPAC items were intensely understood, realized, and executed by the student of the junior high-school SMP Pangudi Luhur Yogyakarta. From the 10 items with the lowest scores, it could be obtained 10 items of the instrument with the lowest score as follows:

Table 4. Ten Items of IASPAC with lowest Scores

\begin{tabular}{|c|c|c|c|}
\hline No & Item No & Item & Score \\
\hline 1 & $\begin{array}{l}\text { Item } \\
34\end{array}$ & I can express my feeling that I am experiencing. & 488 \\
\hline 2 & $\begin{array}{l}\text { Item } \\
21\end{array}$ & I do not have any alternative solution every time I get into troubles. & 493 \\
\hline 3 & $\begin{array}{l}\text { Item } \\
28\end{array}$ & $\begin{array}{l}\text { I always communicate with other people in words that are not } \\
\text { hurting other people's feeling. }\end{array}$ & 500 \\
\hline 4 & $\begin{array}{l}\text { Item } \\
25\end{array}$ & $\begin{array}{l}\text { I do not know at all how to apply the skills to find the solution to the } \\
\text { problems that have not been well solved. }\end{array}$ & 501 \\
\hline 5 & $\begin{array}{l}\text { Item } \\
23\end{array}$ & I am confused to whom should I ask for help if I face problems. & 502 \\
\hline 6 & $\begin{array}{l}\text { Item } \\
26\end{array}$ & $\begin{array}{l}\text { I do not know what kind of friendship situation that influences me to } \\
\text { make decision in solving the problem. }\end{array}$ & 504 \\
\hline 7 & $\begin{array}{l}\text { Item } \\
19\end{array}$ & I solve the problem without any careful consideration & 505 \\
\hline 8 & $\begin{array}{l}\text { Item } \\
29\end{array}$ & I recognize the values that I believe in my life. & 507 \\
\hline
\end{tabular}




\begin{tabular}{llll}
\hline No & Item No & Item & Score \\
\hline 9 & $\begin{array}{l}\text { Item } \\
18\end{array}$ & I always apply the right way to control myself in my life & 512 \\
\hline 10 & $\begin{array}{l}\text { Item } \\
35\end{array}$ & $\begin{array}{l}\text { In solving the problems I always make decision that is safe for } \\
\text { myself }\end{array}$ & 514 \\
\hline
\end{tabular}

Based on the above table, there were 10 items of IASPAC with the lowest scores. Each item was, then, determined as the base to compose the guidance topics to improve the students' social personality autonomy competence in junior highschools, especially in relation to the content of that instrument.

Based on the research result, generally the level of students' social personality autonomy competence in one of the private junior high-schools in Yogyakarta was in the category "high", and there were not any students in the category "Low" and "Very Low". It means that the students in one of the private junior high-schools in Yogyakarta were successful in establishing social personality autonomy competence as a part of the developmental tasks, both in thelevel of knowledge and in the level of behavior.

It was different from the research by Permana (2011: 75-78) in the state junior high-schools SMPN 3 Margahayu, Grade VII describing that there were127 students whose level of autonomy was not yet optimal and 31 students having optimal level of autonomy. The research result by Permana was in linewith the research result by Sadiyah (2008: 57) that described the level of autonomy of 150 Grade XI students in Senior High-school SMA Negeri 1 Soreang with 10\% were in the category "very high', $63 \%$ in the category "high", and $27 \%$ in the category "medium". From that research, $27 \%$ of the students' autonomy was not yet optimal. This means that the school factors with all aspects influence the shaping of the autonomy of students (Ali, M and Asrori, M, 2009: 118). This one of the private junior high-schools in Yogyakarta was presumed to have the curriculum that realized in many kinds of activities. That curriculum provides focus on shaping the students' autonomy.

According Steinberg (1993), the indicators of adolescents who have autonomy in behavior (1) having the ability to make decision that is indicated by: realizing the risk as a consequence of their behavior, choosing the alternative solution based on personal and other people's consideration and being responsible for the consequence of the decision they make; (2) having the strengths to prevent the influence from other people that is marked by: being hard to get influenced in a situation they require conformity, being not easy to get influenced with the pressures from the peers or parents when making decision, and integrating the social group without any pressure; and (3) having confidence which is indicated by: being able to carry out responsibility at home and at school, being able to fulfill the daily needs at home and at school, being able to solve the problems by themselves, and be brave to express the ideas.

The autonomy is the most significant part of the adolescent developmental tasks (Daddies and Smetana, 2006). Salzman (Yusuf, 2008) states that the 
adolescence is indicated with (1) the rise of dependent behavior to their parentto being independent, (2) sexual interest, and (3) tendency to ponder or pay attention to themselves, ethical values, and moral issues.

In achieving the autonomy, one of this is autonomy in social personality; the adolescents often have different opinion from their parents so it is possible that the conflict happens between the adolescent and their parents. This is in line with Thornburg's opinion (Aprilia, 2011) which elaborate that in the effort to achieve the autonomy, the adolescents sometimes oppose, debate, argue, and criticize the parents' attitudes very hard. The autonomy for adolescents is a very important thing. Starting from the importance of achieving the autonomy in the adolescence period, just as explained above, it is necessary to take action, both preventive and curative to follow up that idea.

The most intense topics of autonomy in social personality based on the item analysis is ten (10) items. The low intense topics of autonomy in social personality is linked to the problem solving, self-control, knowledge of life values, friendship, first aid, communicating with others, and expressing the feeling, self-control, knowledge of the value of life, friendship, first aids amidst problems, problem solving, communication skills, and expressing feelings. These findings correspond to the findings by Barus (2012) in his research on the disclosure of the sociopsychological problems of the elementary school students. In the aspect of social personality, the most intense problem the grade 2-4 elementary school students face, among others: being afraid of telling/acting honestly, being impolite/unkind, violating the school regulation, doing bad things, being less respect to adults, being less responsible, and being not committed to the promises. It means that the problems of autonomy in the social personality lie more in the relation to other people.

Examining the composition of the distribution of rank value of the item intensity in the social personality identified in this research, it is very possible to compose the topics of classical or in group guidance services which is preventive for the junior high-schools students. Classical or in group guidance services is one of the basic service strategies which are directly given to the students in the comprehensive guidance and counseling which preventive to all students (ASCA, 2012). Hence it is needed to consider some methods or approaches to classical or in group guidance to help student improve the autonomy in the aspect of social personality, for example, experiential learning based group guidance services (Sinaga, 2013).

\section{Conclusions}

Some conclusions that can be drawn from this research are as follows.

First, most (73.7\%) students in one of the private junior high-schools in Yogyakarta had social personality autonomy competence in the category "high". Few (12.7\%) were in the category "very high", and $13.4 \%$ were in the category "medium". Second, there is a discrimination of the level of social personality autonomy competence among Grades VII, VIII, and IX. The level of social personality autonomy competence of the Grade VII students was better compared with Grade VIII and IX students. Finally, it had been identified that there were ten 
items of IASPAC with the lowest scores showing that the students in one of the private junior high schools in Yogyakarta with low intensity of autonomy in the aspect of social personality in the 10 items of that instrument. The ten items of the instrument were, then, determined as the base to compose the guidance topics that are preventive to improve the autonomy in social personality aspects.

\section{References}

Ali \& Asrori. (2009). Psikologi remaja pengembangan peserta didik. (6 $6^{\text {th }}$ ed.). Jakarta: PT. Bumi Aksara.

Aprilia, I. D. (2011). Pengembangan kemandirian remaja tuna rungu. Retrieved on April 10, 2016, from http://file.upi.edu/

ASCA. (2004). ASCA national standards for students. Alexandria: ASCA.

ASCA. (2012). ASCA national model: A framework for school counseling programs. ( ${ }^{\text {rd }}$ ed.). Alexandria: ASCA.

Barus, G. (2012). Pengungkapan masalah-masalah sosiopsikologis siswa sekolah dasar. Jurnal Penelitian, 15(2), 237-252.

Daddies \& Smetana. (2006). Middle class African American families: Expectations for adolescent behavioral autonomy. International Jurnal of Behavioral Development, 29 (5), 371-381.

Direktur Jendelar Peningkatan Mutu Pendidikan dan Tenaga Pendidikan, Departemen Pendidikan Nasional. (2007). Rambu-rambu penyelenggaraan bimbingan dan konseling dalam jalur pendidikan formal. Jakarta: Dirjen PMPTK.

Hurlock, E. B. (2004). Developmental psichology: A life span approach. (Istiwidayanti \& Soedjarwo, Trans.). Jakarta: Erlangga. (Original work publised 1980).

Kail, R.V., \& Cavanaugh, J.C. (2007). Human development: A life-span view. $\left(4^{\text {th }}\right.$ ed.). Canada: Thomson.

Kartadinata, S., et al. (2003). Pengembangan perangkat lunak analisis tugas perkembangan siswa dalam upaya meningkatkan mutu layanan dan manajemen bimbingan dan konseling di sekolah. Laporan Riset Unggulan Terpadu VIII (unpublished). Jakarta: Kementrian Riset dan Teknologi RI, LIPI.

Kemendikbud RI. (2006). Standar kompetensi lulusan untuk satuan pendidikan dasar dan menengah. Jakarta: Kemendikbud RI.

Makmun, A. S. (2003). Psikologi kependidikan: Perangkat sistem pengajaran modul. Bandung: Rosda.

NN, (2009). Tawuran antara pelajar DKI Jakarta. Retrieved on April 7, 2016, from http://tawuran-kelompokbsi.blogspot.com

NN. (2010). Penelitian mengenai kekerasan di sekolah (2008). Retrieved on April 7, 2016, from http://sejiwa.org/penelitian-mengenai-kekerasan-di-sekolah$2008 /$

Nurihsan, A. J. (2006). Bimbingan dan konseling dalam berbagai latar kehidupan. Bandung: Refika Aditama. 
Permana, M. (2011). Program BK untuk meningkatkan kemandirian siswa; Penelitian pra-eksperimen terhadap siswa kelas IX SMPN 3 Margahayu tahun ajaran 2010/2011. Unpublished thesis.

Prayitno. (1997). Pelayanan Bimbingan dan Konseling di SMP. Jakarta: PT.Ikrar Mandiriabadi.

Rusmana, N. (2009). Bimbingan dan konseling kelompok di sekolah. Bandung: Rizqi.

Sadiyah, E. (2008). Program bimbingan pribadi sosial untuk mengembangkan kemandirian siswa. Unpublished thesis.

Sinaga, J. D. (2013). Efektivitas program bimbingan pribadi-sosial berbasis experiential learning untuk meningkatkan karakter humanis siswa sekolah menengah pertama. Widya Dharma, Jurnal Pendidikan, 25 (1), 104-121.

Steinberg, L. (1993). Adolescence. ( $3^{\text {rd }}$ ed.). New York: McGraw-Hill, Inc.

Sudianto, A., \& Juntika, N. (2005). Manajemen bimbingan dan konseling di SMA kurikulum 2004. Jakarta: Grafindo.

Sugiyono. (2010). Metode penelitian pendidikan, pendekatan kuantitatif, kualitatif, dan $R \& D$. Bandung: Alfabeta.

Yusuf, L.N. (2006). Psikologi perkembangan anak dan remaja. Bandung: Rosda.

Yusuf, L.N. (2009). Program bimbingan dan konseling di sekolah (SLTP dan SLTA). Bandung: Rizqi Press.

Winkel, W.S. (1997). Bimbingan dan konseling di institusi pendidikan. Jakarta: Grasindo. 